Jurnal Konstruksi Hukum | ISSN: 2746-5055

Vol. 2, No. 3, September 2021 Hal. 575-581 | Tersedia online di https://www.ejournal.warmadewa.ac.id/index.php/jukonhum DOI:https://doi.org/10.22225/jkh.2.3.3644.575-581

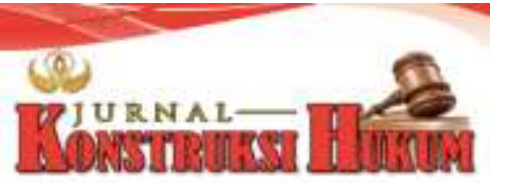

\title{
KEWENANGAN KEPOLISIAN DAERAH BALI DALAM PENEGAKAN HUKUM TERHADAP AKSI UNJUK RASA YANG ANARKIS
}

\author{
I Nyoman Budiantara, Anak Agung Sagung Laksmi Dewi, Nyoman Sutama \\ Fakultas Hukum, Universitas Warmadewa, Denpasar - Bali, Indonesia \\ Nyomanluliantra@gmail.com, laksmidewi29@gmail.com, nyomansutama@gmail.com
}

\begin{abstract}
Abstrak
Kemerdekaan menyampaikan pendapat di muka umum merupakan hak setiap warga negara yang dilindungi oleh undang-undang. Ada beberapa asas yang harus diikuti dalam menyampaikan pendapat di muka umum yaitu asas keseimbanganan berhak dan kewajiban, musyawarah mufakag kepastian hukum dan keadilan, proporsionalitas, dan manfaat. Namun faktanya unjuk rasa yang dilakukan seringkali dilakukan secara anarkis. Tujuan dari penelitian ini yaitu untuk mengetahui kewenangan kepolisian daerah Bali dalam penegakan hukum terhadap aksi unjuk rasa yang anarkis, dan mengetahui hambatan-hambatan yang dihadapi oleh kepolisian Bali dalam menangani aksi unjuk rasa. Penelitian ini me nggunakan penelitian hukum empiris karena kesenjangan antara teori dengan realita. Hasil penelitian bahwa Kewenangan Kepolisian Daerah Bali dalam penegakan hukum terhadap aksi unjuk rasa anarkis mengacu pada UU/8/1998 dan Peraturan Kapolri No. Pol. 16 Tahun 2006, serta Protap No. PROTAP/1/X/2010. Hambatan Polda Bali dalam menangani aksi unjuk rasa anarkis terbagi menjadi faktor penghambat intemal seperti faktor pengetahuan, emosi, dan keterlambatan informasi. dan ekstemal seperti tidak ada izin unjuk rasa, terpengaruh minuman keras. Kepada masyarakat, untuk selalu mematuhi peraturan perundang-undangan dalam hal unjuk rasa.
\end{abstract}

Kata Kunci: Anarkis, Kepolisian, Penegakan Hukum.

\begin{abstract}
Freedom of expression in public is the right of every citizen which is protected by law. There are several principles that must be followed in expressing opinions in public, namely the principle of balancing rights and obligations, deliberation and consensus, legal certainty and justice, proportionality, and benefits. However, the fact is that demonstrations are often carried out in an anarchic manner. The purpose of this study is to determine the authority of the Bali police in law enforcement against anarchic demonstrations, and to find out the obstacles faced by the Balinese police in dealing with demonstrations. This study uses empirical legal research because of the gap between theory and reality. The results of the research that the authority of the Bali Regional Police in law enforcement against anarchist demonstrations refers to Law/8/1998 and the National Police Chief Regulation No. Pol. 16 of 2006, as well as Protap No. PROTAP/1/X/2010. Barriers to the Bali Police in dealing with anarchic demonstrations are divided into internal inhibiting factors such as knowledge, emotions, and delays in information. The external such as no permission to protest, influenced by alcohol. To the public, to always comply with the laws and regulations in terms of demonstrations.
\end{abstract}

Keywords: Anarchists, Police, Law Enforcement.

\section{PENDAhuluan}

Undang-undang Dasar Negara Republik Indonesia Tahun 1945 dalam Pasal 1 ayat (3) menegaskan bahwa Wilayah Indonesia adalah negara hukum (Pasha, 2000) Sertifikasi hukum dan ketertiban menyimpulkan bahwa setiap aktivitas negara dan pendudu $\mathrm{k}$ harus didasarkan dan bergantung pada hukum. Pedoman lebih lanjut mengenai pameran dipastikan dalam Pasal 28 Undang-undang Dasar Negara Republik Indonesia Tahun 1945 yang menyatakan bahwa peluang untuk berafiliasi dan berkumpul, mengomunikasikan pertimbangan secara lisan dan direkam dalam bentuk hard copy, dll akan diatur dengan undang-undang. Negara Republik Indonesia adalah negara hukum. Parameter negara hukum diukur dari terpenuhinya berbagai unsur-unsur kategorikal, seperti supremasi hukum (supremacy of law), persamaan dalam hukum (equality before the law), proses hukum yang adil (due process of law), peradilan bebas dan tidak memihak (independence and impartiality of judiciary) dan lain sebagainya hukum oleh negara untuk merepresi rakyatnya (Winarta, 2011).

Berdasarkan konfirmasi, karena kekuasaan pada dasamya datang dari individu, diawasi oleh individu, dan untu $\mathrm{k}$ membantu setiap individu, kesempatan untuk mengkomunikasikan perasaan baik 
yang direkam dalam bentu $\mathrm{k}$ hard copy mau pun secara lisan dijamin oleh hukum. Jadi tayangantayangan di Indonesia setiap hari sudah menjadi pemanfaatan pu blik, hal ini bisa dilihat di layar-layar TV dan di koran-koran di mana tayangan diadakan untuk membu barkan tayangan badan publik yang tidak berpihak pada kepentingan individu (Hadjon, 2005).

Kebebasan menyampaikan pendapat ini dikembangkan kembali dalam Undang-undang No. 9 Tahun 1998 tentang Kemerdekaan Menyampaikan Pendapat di Muka Umum (Syamsir, 2015). Kemerdekaan ini terlihat pada Pasal 1 Angka 1 yang menyatakan bahwa "Kemerdekaan menyampaikan pendapat adalah hak setiap warga negara untuk menyampaikan pikiran dengan lisan, tulisan dan sebagainya, secara bebas dan bertanggung jawab sesuai dengan ketentuan peraturan perundang-undangan yang berlaku". Dalam pelaksanannya, penyampaian pendapat ini tidak selamanya berjalan dengan aman serta tertib kadang kala terjadi berbagai bentuk pelanggaranpelanggran yang berujung pada tindakan anarkis yang tentunya perlu mendapat perhatian lebih oleh pihak kepolisian (Syahbana, 2013).

Sejalan dengan itu , kesempatan untuk mengkomunikasikan perasaan secara terbuka harus dilaksanakan dengan tugas penuh, sesuai dengan pengaturan huku $\mathrm{m}$ dan pedoman terkait dan standar hukum dunia. Kesempatan untu k mengkomunikasikan penilaian ini terkandung dalam Pasal 29 Pengumuman Semua Termasuk Kebebasan Dasar yang, di camping hal-hal lain, menentu kan yang menyertai. Setiap orang mili ki komitmen terhadap masyarakat yang memberdayakan peningkatan karakter secara bebas dan penuh. Dalam aktivitas hak dan kesempatannya, setiap individu harus menyetujui secara eksklusif batasan yang ditentukan oleh hukum untu $\mathrm{k}$ memastikan pengakuan dan penghormatan terhadap hak dan kesempatan orang lain dan untuk memenuhi syarat sederhana untu $\mathrm{k}$ kualitas yang mendalam, permintaan, dan bantuan umum pemerintah dalam masyarakat berbasis popularitas.

Dengan cara apapun, bentu $\mathrm{k}$ atau bentuk hak dan peluang ini tidak dipraktikkan dengan mengabaikan tujuan dan standar Negara Bersatu. Terkait pendorong di bidang hukum yang menggabungkan materi yang sah, perangkat yang sah, tempat kerja dan tempat kerja yang sah, budaya yang sah dan peluang agregat, pakar publik Republik Indonesia wajib menunju kkan sikap politi k yang penuh harapan tentang keterusterangan yang dikembangkan. juga, eksekusi hukum.

Berawal dari pendekatan pembenahan yang halal, baik menurut perspektif kepentingan umum sampai kepentingan relasi antar negara, peluang untuk mengkomunikasikan sentimen secara terbuka sebagaimana diputuskan dalam klarifikasi Undang-undang $\mathrm{N}$ oreor 9 Tahun 1998 tentang Kesempatan Berkomunikasi. Anggapan tersebut harus dilandasi pada beberapa asas diantaran ya

1. Asas keseimbangan antara hak dan kewajiban

2. Asas musyawarah dan mufakat

3. Asas kepastian hukum dan keadilan

4. Asas proporsionalitas

5. Asas manfaat.

Kelima standar tersebut adalah pembentu kan peluang yang bertanggung jawab atas dedu ksi dan bertindak untuk mengkomunikasikan penilaian secara terbuka. Mengingat lima standar kesempatan untuk mengkomunikasikan perasaan di siang hari bolong, pelaksanaann ya diperlukan untu $\mathrm{k}$ mencapai tujuan Mengakui kesempatan yang mampu sebagai salah satu kebebasan bersama sesuai Pancasila dan U UD 1945. Mengakui keamanan sah yang dapat diprediksi dan masu k akal dalam memastikan peluang art ikulasi mewujudkan lingkungan yang bermanfaat bagi peningkatan inv'estasi dan imajinasi setiap penduduk sebagai contoh hak dan kewajiban dalam kehidu pan yang berkeadilan.

Menetapkan tugas sosial dalam keberadaan masyarakat, negara dan negara, tanpa mengabaikan kepentingan individu atau pertemuan. Menyikapi hal tersebut, maka yayasan kepolisian merupakan salah satu lembaga yang memiliki keahlian di bidang keamanan dan permintaan masyarakat. Hal tersebut ditegaskan dalam Pasal 2 Undang-undang Nomor 2 Tahun 2002 tentang Kepolisian Negara yang menegaskan bahwa fungsi kepolisian adalah salah satu fungsi pemerintahan di bidang pemeliharaan keamanan dan ketertiban masyarakat, penegakan hukum, perlindungan, pengayoman, dan pelayanan kepada mas yarakat.

Atas desakan tersebut, polisi diharapkan memiliki opsi untu $\mathrm{k}$ tetap membuka kesejahteraan terhadap pameran yang terjadi. Berdasarkan klasifikasi tersebut, tainpaknya antara apa yang diatur dalam peraturan perundang-undangan dan pedoman di Indonesia terkait dengan pertunju kan, pelaksanaannya bertentangan dengan huku $\mathrm{m}$ mengingat dalam pameran yang dilakukan oleh 
masyarakat pada umumnya masih sering dilaku kan. dilengkapi dengan pameran yang digabungkan dengan perilaku anarkis. Pada premis ini, penulis tertarik pada pemeriksaan terkemu ka sebagai tugas akhir dengan judul Kewenangan kepolisian daerah Bali dalam penegakan hukum terhadap aksi unjuk rasa yang anarkis.

Pengamanan unjuk rasa merupakan bagian dari peran dari fungsi kepolisian. Unjuk rasa merupakan salah satu bentuk dalam rangka penyampaian pendapat di muka umum dimana menyampaikan pendapat di muka umum tersebut merupakan hak setiap warga negara yang diatur dalam Pasal 28 E UUD 1945. Penanganan unjuk rasa oleh pihak kepolisian yang meliputi penyelenggaraan pelayanan, penyelenggaraan pengamanan dan penanganan perkara, dan bentuk diskresi kepolisian dilakukan dengan cara melakukan tindakan kepolisian lainnya yang dapat dipertanggungjawabkan (Priyantoko, 2016). Kepolisian Dalmas Polda Bali dalam menegakan hukum terhadap aksi unjuk rasa dilakukan berdasarkan tindak pre-emtif, preventif serta tindakan represif yang berpedoman pada peraturan perundang-undangan serta peraturan-peraturan Kapolri tentang penanganan unjuk rasa (Kadek Windi Pranata Putra, Ida Ayu Putu Widiati, I Nyoman Gede Sugiarta). Aksi unjuk rasa menyebabkan kerugian baik warga masyarakat, pemerintah, sekolah, maupun perusahaan swasta dikarenakan sejumlah sekolah diliburkan, perusahaan meliburkan karyawannya. Sejumlah titik jalan dikabarkan ditutup sehingga menyebabkan masyarakat putar balik lebih jauh untuk sampai ke tujuannya (Sitinjak \& Sugama, 2020).

Dari penjelasan diatas tujuan dari penelitian ini yaitu untuk mengetahui kewenangan kepolisian daerah Bali dalam penegakan hukum terhadap aksi unjuk rasa yang anarkis, dan mengetahui hambatan-hambatan yang dihadapi oleh kepolisian Bali dalam menangani aksi unjuk rasa.

\section{METODE PENELITIAN}

Penelitian ini menggunakan metode penelitian hukum empiris karena terjadi kesenjangan antara teori dengan realita. Dimana dalam pasal 1 ayat (3) Undang-undang Dasar Negara Republik Indonesia Menegaskan Bahwa Setiap Tindakan negara dan warga negara harus berdasarkan dan berlandaskan atas hukum dan lebih lanjut dalam pasal 6 huruf (d) Undang-undang Nomor 9 Tahun 1998 Tentang Kemerdekaan Menyampaikan Pendapat Dimuka Umum, menegaskan bahwa warga negara yang menyampaikan pendapat di muka umum wajib menjaga dan menghormati keamanan dan ketertiban umum. Jenis Pendekatan dal are penelitian ini penulis menggunakan beberapa pendekatan, yakni pendekatan Undang-undang adalah pendekatan yang dilengkapi dengan memeriksa Undang-undang dan pedoman yang mengidentifikasi dengan masalah sah yang sedang ditangani (Marzuki, 2005). Pendekatan Faktanya adalah pendekatan yang digunakan dengan mengedepankan fakta-fakta yang terjadi dilapangan, dalam hal adanya unjuk rasa yang anarkis. Pendekatan konsep merupakan pendekatan yang dilakukan dengan mengu mpulkan pandangan-pandangan dari doktrin-do $\mathrm{km}$ in yang berkembang di ilmu hukum yang dikemukakan oleh ahli-ahli hukum. Pendekatan kasus merupakan pendekatan yang dilakukan dengan menelaah kasus yang berkaitan dengan isu hukum yang akan dibahas atau dalam hal ini yang berkaitan dengan aksi unju $\mathrm{k}$ rasa yang anarkis.

\section{HASIL PENELITIAN DAN PEMBAHASAN}

\section{Kewenangan Kepolisian Daerah Bali Dalam Penegakan Hukum Terhadap Aksi Unjuk Rasa yang Anarkis Kedudukan Kepolisian Republik Indonesia}

Sesuai dengan kamus bahasa Indonesia secara keseluruhan, yang tersirat dalam buku menyatakan bahwa stru ki ur adalah bagaimana sesuat u didalangi, diatur atau dirakit. Tindakan didalangi secara benahap yang terdiri dari bagian-bagian atau komponen yang saling ber hubungan satu sama lain bekerja sama untu k mencapai tujuan hierarkis (Purwodarminto, 1986).

Pembangunan otoritatif yang berkembang dari tingkat basecamp ke tingkat lokal pada dasamya menekankan pembagian zona yang sah dan tugas untuk mencapai tujuan hierarkis. Berdasarkan Keppres Nomor 70 Tahun 2002 tersebut stru ktur organisasi di tingkat M abes Polri memiliki unsurunsur yang terdiri dari:

1. Unsur Pimpinan

2. Unsur pembentu pimpinan dan pelaksana staf

3. Unsur Pelaksana Pendidikan dan atau/Pelaksana Staf Khusus

4. Unsur Pelaksana Utama Pusat

5. Satuan organisasi penunjang lainnya. 
Tindak lanjut dari Keputusan Presiden Nomor 70 Tahun 2002 tersebut kemudian dikeluarkan Keputusan Kapolri Nomor Pol. Kep/ 53/X/2002 tanggal 17 Oktober 2002 tentang Perkumpulan dan Tata Kerja Satuan Hierarki di Tingkat Basecamp Kepolisian Negara Republik Indonesia yang kemudian dikoreksi dengan Pengumuman Kapolri Nomor Pol.Keadaan kepolisian tidak terkontrol secara jelas dan tidak tergoyahkan dalam Undang- Undang Dasar Negara Republik Indonesia Tahun 1945.

Dalam beberapa peraturan perundang-undangan, tepatnya pasal 30 ayat (4) IN ndangUndang Dasar Negara Republik Indonesia Tahun 1945, Pasal 6 ayat (1) Pengumuman MPR R1 Nomor VII / MPR / 2000, dan pasal 5 ayat (1) Undang- Undang Nomor 2 Tahun 2002, bahwa Kepolisian Negara Republik Indonesia sebagai alat negara melengkapi salah satu unsur pemerintahan, khususnya di bidang menjaga keamanan dan permintaan masyarakat melalui pemberian jaminan, jaminan dan administrasi ke daerah setempat dan penerapan hukum. Pengaturan Kewenangan Lembaga Kepolisian Republik Indonesia dalam Penegakan hukum aksi unjuk rasa yang anarkis

1. Landasan yuridis susunan kepolisian ini diatur dalam pasal 3 ayat (1), ayat (2) dan ayat (3)

2. Keputusan Presiden $\mathrm{N}$ omor 70 Tahun 2002 yang su bstansinya, sebagai berikut.

3. Organisasi Polisi Umum diorganisir secara bertahap dari tingkat pusat hingga lokal.

4. Organisasi Polri tingkat pu blik dikenal sebagai Markas Polisi U mum Republik Indonesia, yang disingkat sebagai Mabes Polri.

5. Organisasi Polri di tingkat provinsi disebut Polisi Daerah, disingkat Polda.

Berdasarkan ketentuan pasal 7 ayat (1) Ketetapan M PR R1 No. VII/MPR/2000 dan pasal 5 ayat t2) Undang-undang N o. 2 Tahun 2002, bahwa Kepolisian Negara Republik Indonesia adalah Kepolisian Nasional yang merupakan bagian penting dari melakukan kewajiban hierar kis dan sengaja, menerapkan hukum, seperti memberikan asuransi, jaminan, dan administrasi ke area lokal dalam struktur menjaga keamanan yang tumbu $\mathrm{h}$ di dalam negeri. Jadi polisi umum di sini menyiratkan bahwa mereka bu kanlah polisi terdekat yang independen dan tetap menyendiri di setiap lingkungan atau lokal.

Dengan demikian, wilayah di dalam suatu daerah menjadi tempat tinggal Polisi Daerah (Polda) dalam menyelesaikan kewajiban dan tugasnya. Kewenangan Kepolisian Sebagaimana diindikasikan oleh Undang- undang Dasar Negara Republik Indonesia Tahun 1945 Dalam Koreksi U UD 1945, kewajiban dan keahlian kepolisian diat ur dalam pasal 30 ayat (4) yang berbunyi Kepolisian Negara Republik Indonesia sebagai instrumen ekspres yang menjaga keamanan dan permintaan masyarakat yang menjamin, menopang, melayani daerah setempat, dan mengesahkan hokum.

Undang-undang Nomor 2 Tahun 2002 tentang Kepolisian Negara Republik Indonesia, tidak mengatur kewenangan kepnlisian dalam pengaturan pertunjukan namun dalam undang- undang ini terdapat pasal-pasal yang dapat dieksekusi sebagai kewenangan kepolisian dalam kewenangan penyelenggaraan pameran. Artikel ini akan menjadi Pasal 13 tentang kewajiban dan spesialis kejx $>$ lisian, dal am pasal 13 tersebut menyebutkan tugas dan wewenang polisi yang menegaskan bahwa tugas pokok Kepolisian Negara Republik Indonesia adalah:

1. Memelihara keamanan dan ketertiban masyarakat

2. Menegakkan huku m, dan

3. Memberikan perlindungan, pengayoman, dan pelayanan kepada masyarakat Pasal 18 ayat (1) menyatakan bahwa barangsiapa melalui kebiadaban atau bahaya kebrutalan menghalangi hak warga negara untu k mengkomunikasikan tindakan secara terbuka yang telah memenu hi ketentuan hukum akan dipidana dengan pidana kurungan paling lama 1 (satu) tahun sebagai langkah yang dilakukan oleh ke \}xilisian, karena sesuai dengan kewajiban pokok kepolisian, secara spesifik

1. Menjaga keamanan dan permintaan masyarakat

2. Menjaga hukum dan Memberikan keamanan, asuransi, dan pemerintahan daerah setempat.

Dari penjelasan di atas, maka sangat dapat dimaklumi bahwa sebagai alasan yang sah bagi polisi dalam menangani tindakan, ha1 itu menyinggung 2 landasan hukum, yaitu Undang- Undang Nomor 2 Tahun 2002 tentang Kepolisian Negara Republik Indonesia dan IN ndang- Undang Nomor 9 Tahun 1998 tentang Kepolisian Negara Republik Indonesia. Pelaksanaan Penyampaian Anggapan Populer. Hambatan-Hambatan Yang Dihadapi Oleh Kepolisian Daerah Bari Dalam Menangani Aksi Unjuk Rasa yang Anarkis

Hambatan Yang Dihadapi Oleh Kepolisian Daerah Bali Dalam Menangani Aksi unjuk Rasa yang Anarkis Kepolisian Daerah Bali atau disebut dengan Polda Bali meru pakan kesatuan pelaksana 
tugas keamanan Negara Republik Indonesia di wilayah teritorial Provinsi Bali. Dalam pelaksanaan, penyampaian pendapat ini tidak selamanya berjalan dengan aman serta tertib kadang $\mathrm{km} \mathrm{u}$ terjadi berbagai bentuk pelanggaran- pelanggaran yang berujung pada tindakan anarkis yang tentunya perlu mendapat per hatian lebih oleh pihak kepolisian.

Atas dasar tersebut maka berdasarkan hasil wawancara dengan AKP 1 Nyoman Budiasa, dengan jabatan Dankie 11 Sipasdal Subdit Dalmas Samapta Polda Bali, pada hari ju mat 5 Maret 2021 adapun Faktor-penghambat atau kendala-kendala dalam penanganan aksi unjuk Rasa oleh Anggota Kepolisian Polda Bali Pada pelaksanaan kegiatan unjuk rasa di Bali terdapat beberapa kendala atau faktor penghambat penanganan aksi unjuk rasa oleh anggota kepolisian Polda Bali, faktor penghambat tersebut terbagi menjadi faktor penghambat yakni penghambat atau kendal a intemal dan ekstemal, yaitu :

1. Faktor intemal yang dimaksud adalah faktor yang asalnya dari dalam Lembaga kepolisian polda Bali itu sendiri. Faktor ini biasanya berupa sikap juga sifat yang melekat pada Lembaga tersebut. Adapun Faktor intemal tersebut adalah terdapat anggota Dalmas yang kurang paham akan penetapan aturan sena prosedur penangan unjuk rasa, kadang kala anggota di lapangan tidak dapat mengontrol emosi terhadap perkataan maupun perbuatan yang dilakukan oleh massa pengunjuk rasa Kadangkala terjadi keterlambatan informasi yang didapatkan saat terjadinya unjuk rasa, sehingga terdapat beberapa penanganan unjuk rasa yang dilakukan secara tergesa-gesa tanpa mempersiapkan alat yang matang Dalam unju k rasa kerap kali dil aku kan dengan berjalan kaki menuju titik satu ke titik yang lainnya dengan estimasi jarak yang cu ku p jauh sehingga menyulitkan anggota memberikan pengamanan sekaligus mengatur lalu lintas yang termasuk melaksanakan rekayasa lalu lintas sehingga kegiatan unjuk rasa dapat berjalan dengan aman dan lancar tanpa terlalu memberatkan dan mengganggu aktis'itas masyarakat lainnya.

2. Faktor Ekstemal yang dimaksud adalah faktor yang asalnya dari luar organ kelembagaan. Faktor ini meliputi lingkungan di sekitar termasu k kelembagaan lain. Adapun Faktor penghambat ekstemal tersebut.Penanggung jawab demonstran tidak menyampaikan pemberitahuan atau mencari izin untuk melakukan aksi unju k rasa. Atau dalam pelaksanaan unju k rasa, koordinasi pelaksanaan dilakukan secara mendadak. Adanya susu pan pendemo di luar sepengetahuan penanggung jawab aksi unjuk rasa. Para demonstran kesadarannya dipengaruhi oleh minu man keras sehingga susah untu $\mathrm{k}$ diberikan arahan. Adanya massa bayaran yang dibayar untu $\mathrm{k}$ memperkeruh suasana atau memberikan provokasi agar aksi unju $\mathrm{k}$ rasa menjadi ricuh atau anarkis. Perlunya peningkatan terhadap pemahaman serta penerapan hu ku $\mathrm{m}$ oleh masyarakat sehingga dapat meminimalisir aksi unju k rasa anarkis yang berujung pada pembakaran ban atau pun penangkapan oknum pengunjuk rasa yang menyal ahi aturan pelaksanaan unjuk rasa. Dalam penanganan unjuk rasa kerap kali massa pengunjuk rasa yang menuju titik ku mpul pelaksanaan unju k rasa menggunakan kendaraannya secara ugal-ugalan, tidak menggunakan helm serta secara bergerombolan di jalan melanggar lalu lintas menuju lokasi titik kumpul tersebut Dalam pelaksanaan unju $\mathrm{k}$ rasa beberapa kali massa tidak bisa mengendali kan emosinya sehingga melakukan tindakan-tindakan serta ucapan-ucapan yang cenderung meni mbulkan rasa emosi bagi anggota Dalmas yang memberikan pengamanan terhadap aksi unjuk rasa.

upaya penanggulangan kepolisian daerah Bali dalam meminimalisir aksi unjuk rasa yang anarkis Untu $\mathrm{k}$ meminimalisir dan menanggulangi faktor penghambat tersebut di atas Polda Bali memiliki cara-cara atau strategi sebagai bentu $\mathrm{k}$ antisipasi untu $\mathrm{k}$ meminimalisir kejadian yang tidak diinginkan Yang berhubungan dengan aksi unju $\mathrm{k}$ rasa anarkis sesuai dengan kedudu kan Polda bali dalam menjalankan tugas dan fungsinya diantaranya sebagai berikut. Upaya Preventif yang dimaksud adalah tindakan untuk mengantisipasi terjadinya aksi unjuk rasa yang anarkis. Meskipun demikian, pendekatan preventif ini tidak berkhak ditangani oleh hukum pidana melainkan sebagai suatu kegiatan untuk membuang komponen-komponen potential penyebab kemunculannya aksi unjuk rasa yang anarkis. Adapun cara atau strategi sebagai bentuk antisipasi tersebut tersebut berupaya dalam persiapann, setiap hari anggota Dalmas Polda Bali melaksanakan kegiatan- kegiatan Dalmas yang diperuntu kan untuk peningkatan Teknik dalam menangani segala jenis unju $\mathrm{k}$ rasa termasuk unju $\mathrm{k}$ rasa tolak reklamasi Telu k Benoa ini. Mempersiapkan peralatan Dalmas yang apabila sewaktu -waktu dibutu hkan. Kesiapan ini berupa pembersihan dan pengecekan bahan bakar yang dilakukan setiap hari serta pengecekan keberfungsian mesin yang dilakukan setiap 1 bulan sekali. Bila terjadi kendala dalam suatu kendaraan agar segera diperbaiki sehingga tidak menimbulkan permasalahan ketika 
digunakan saat pengamanan unjuk rasa.

Diselenggarakan kegiatan Forum Group Diskusi yang dilakukan oleh anggota polri dengan konrdinator massa pengunju krasa tolak reklamasi serta mengikutsertakan berbagai elemen masyarakat agar pelaksanaan unjuk rasa berjalan sesuai dengan ketentuan, dan apabila terjadi unju $\mathrm{k}$ rasa yang di luar ketentuan, pihak kepolisian memberikan larangan langsung agar tindakan tersebut tidak dilakukan kembali.

Pimpinan Dalmas secara langsung memberikan teguran dan arahan apabila terdapat anggotanya dalam pelaksanaan pengamanan unjuk rasa tolak reklamasi Teluk Benoa dan jika sudah melakukan tindakan kepolisian di luar ketentuan.

1. Melakukan patrol wilayah yang disinyalir tempat berku mpulnya demonstrasi.

2. Melakukan koordinasi dengan tokoh masyarakat dan tokoh adat.

3. Memberikan himbauan atau arahan kepada demonstran untuk kembali ke ru matt agar situasi tetap kondusif.

4. Melakukan pendekatan terhadap demonstran agar tidak mengarah ke tempat aksi unjuk

5. Menjalin komunikasi aktif dengan penanggung jawab atau juru bicara.

Upaya Represif yang dimaksud adalah suatu tind akan yang dilakuan setelah terjadi penyimpangan dalam aksi unjuk rasa yang betujuan untuk memulihkan kembali aktifitas publik yang kesal karena penyimpangan sosial dengan memberikan sanksi sesuai dengan pelanggaran yang telah disampaikan dalam pameran. Adapun upaya represif yang dilakukan dalam u paya penanggulangan ter hadap aksi unjuk rasa tersebut adalah

Mendesak demonstran dengan upaya mendorong massa agar mundur dan tidak mengarah ke objek yang dituju.

1. Pembubaran demonstran dengan menggunakan water canon.

2. Penembakan gas air mata untuk melumpu hkan para demonstran yang anarkis.

Melakukan penangkapan terhadap para demonstran yang memprofokasi terjadinya aksi anarkis untu $\mathrm{k}$ diproses sesuai dengan peraturan perundang- undangan yang berlaku. Melakukan penegakan huku m yang mengacu pada ketentuan-ketentuan dalam Undang-undang Nomor 9 tahun 1998 tentang Kemerdekaan Menyampaikan Pendapat yang penanganann ya berpedoman pada Peraturan Kapolri Nomor Pol. 16 Tahun 2006 tentang Pedoman Pengendalian Massa, Prosedur Tetap Nomor PROTAP/1/X/20 10 Penanggulangan Anarki serta Per kapolri Nomor 9 Tahun 2008 Tentang Tata Cara Pen yelenggaraan, Pelayanan, Pengamanan, dan Penanganan Perkara Penyampaian Pendapat di Muka Umum (Suharto \& Efendi, 2014)

\section{SIMPULAN DAN SARA}

\section{Simpulan}

Dari hasil pembahasan penelitian tersebut di atas, maka peneliti dapat menarik 2 (dua) simpulan sesuai dengan permasalahan yang diangkat diant aranya

1. Kewenangan Polda Bali dalam menegakkan hu kurz terhadap unjuk rasa yang anarkis mengacu pada pengaturan dalam Undang-undang Nomor 9 Tahun 1998 tentang Peluang Perasaan Berkomunikasi yang diatur dengan berpedoman pada Pedoman Kapolri Nomor Pol. 16 Tahun 2006 tentang Tata Tenib Pengendalian Massa, Cara Berturut-turut Nomor PROTAP / / X / 2010 Pengurusan Gangguan dan Perkapolri Nomor 9 Tahun 2008 tentang strategi pelaksanaan, penyelenggaraan, pengamanan, dan penanganan perkara untuk penyampaian asesmen secara terbuka.

2. Hambatan-hambatan yang dihadapi oleh Polda Bali dalam mengurus unjuk rasa yang anarkis yang terjadi di Kawasan Bali terbagi menjadi beberapa hambatan yaitu Faktor Intemal dan Ekstemal. Faktor Intemal yang dimaksud adalah faktor-faktor yang dimulai dari dalam Polda Bali itu sendiri. Maka Faktor Ekstemal yang dimaksud adalah fakt or-faktor yang dimulai dari luar organ kelembagaan.

\section{Saran}

Dari hasil penelitian tersebut di atas maka ada beberapa saran sehubungan dengan aksi unjuk rasa yang anarkis diantaranya:

1. Kepada masyarakat, Untuk selalu melakukan tindakan sesuai dengan peraturan perundangundangan dalam hal men yampaikan pendapat melalui unju $\mathrm{k}$ rasa agar terhindar dari kasus hukum. 
2. Kepada aparat penegak hukum, khususnya ke\}xilisian untuk menidak tegas setiap tindakan demonstran yang berpotensi menimbulkan aksi unjuk rasa yang anarkis.

\section{DAFTAR PUSTAKA}

Hadjon. (2005). Hukum Administrasi Negara. Gadjah Mada University Press. Yogyakarta.

Pasha, M. K. (2000). Pancasila dalam tinjauan Historis dan filosofi. Citra Karsa Mandiri. Yogyakarta.

Marzuki, P. M. (2005). Penelitian Hukum Empiris. Kencana Media.

Purwodarminto. (1986). Purwodarminto W 3.S. (1986). Kamus Umum Bahasa Indonesia (p. Hal. 965). Balai Pustaka. Balai Pustaka. Jakarta.

Suharto, \& Efendi, J. (2014). Panduan Praktis Bila Anda Menghadapi Perkara Pidana Mulai Proses Penyelidikan Hingga Persidangan. Prenadamedia Group.Jakarta.

Putra, I. K. W. P., Widiati, I. A. P., \& Sugiarta, I. N. G. (2020). Peran Anggota Kepolisian Dalmas Polda Bali Dalam Penegakan Hukum Terhadap Penanganan Unjuk Rasa Tolak Reklamasi Teluk Benoa. Jurnal Konstruksi Hukum, Vol.1 (2).

Priyantoko, G. (2016). Penerapan Diskresi Kepolisian Dalam Penanganan Unjuk Rasa. De Laga Lata, Vol. 1(1).

Sitinjak, I. V. W., \& Sugama, I. D. G. D. (2020). Diskresi Polisi Dalam Kerusuhan Demonstran Di Indonesia. Kerta Wicara, Vol. 9(7).

Syamsir. (2015). Demokratisasi Hak Berpikir dan Berkreasi Warga Negara di Indonesia. Jurnal Inovarif, Vol.8 (1), 115-133.

Syahbana, M. R. (2013). Penerapan Prosedur Tetap Polri dalam Penanggulangan Unjuk Rasa Anarki. Jumal Ilmu Hukum Legal Opinion, Vol.1 (2), 1-22.

Rahardjo, S. (2009). Negara Hukum yang Membahagiakan Rakyatnya. Genta Publishing, Yogyakarta. Winarta, F. H. (2011). Bantuan Hukum di Indonesia, Hak Untuk Didampingi Penasihat Hukum bagi Semua Warga Negara. PT. Alex Media Komputindo. Jakarta. 